\title{
MANAJEMEN PERPUSTAKAAN DALAM MENINGKATKAN MINAT BACA PESERTA DIDIK
}

\section{A. Heris Hermawan}

Universitas Islam Negeri Sunan Gunung Djati Bandung

Email: herishermawan@uinsgd.ac.id

\section{Wahyu Hidayat}

Universitas Islam Negeri Sunan Gunung Djati Bandung

Email: wahyugarut74@gmail.com

\section{Ilham Fajari}

Universitas Islam Negeri Sunan Gunung Djati Bandung

Email: ilhamfajari777@gmail.com

\begin{abstract}
ABSTRAK
Penelitian ini dilatarbelakangi oleh pengelolaan manajemen perpustakaan, pengembangan koleksi buku, faktor pendukung dan penghambat serta peningkatan minat baca peserta didik. Penelitian ini bertujuan untuk mengetahui peran perpustakaan, yaitu pustakawan, koleksi, manajemen pengelolaan dan meningkatkan minat gemar membaca siswa Madrasah Aliyah Negeri 3 Tasikmalaya. Tujuan penelitian ini adalah untuk mengetahui dan mendeskripsikan perencanaan, pengadaan, pemakaian, penginventarisasian, penghapusan, faktor penghambat dan penunjang perpustakaan di Madrasah Aliyah Negeri 3 Tasikmalaya. Penelitian ini merupakan penelitian kualitatif dengan memakai metode deskriptif. Pengumpulan data dilakukan dengan wawancara, observasi, dan studi dokumentasi. Teknik analisis data dilakukan melalui penafsiran deskriptif, uji keabsahan data, perpanjangan keikutsertaan, dan auditing. Perencanaan perpustakaan dilakukan dengan musyarawah, pengorganisasian dilakukan dengan pemilihan dan disepakati secara bersama, pelaksanaan dilakukan sesuai dengan rencana dan sesuai tugasnya masingmasing serta pengawasan dilakukan tiap hari seperti pengawasan layanan sirkulasi dan kebersihan, kerapihan dan kedisiplinan. Pengembangan koleksi dilakukan dengan musyawarah dan pengajuan dari pemustaka, faktor pendukung adalah fasilitas yang cukup memadai, faktor penghambatnya bahwa pustakawan yang tersedia bukan lulusan dari bidangnya.
\end{abstract}

Kata kunci: Manajemen, Perpustakaan, Minat Baca 


\section{ABSTRACT}

This research is motivated by the management of library management, the development of book collections, supporting and inhibiting factors as well as increasing students' interest in reading. This study aims to determine the role of libraries, namely librarians, collections, management and increase interest in reading students of Madrasah Aliyah Negeri 3 Tasikmalaya. The purpose of this study was to determine and describe the planning, procurement, use, inventory, deletion, inhibiting factors and supporting libraries in Madrasah Aliyah Negeri 3 Tasikmalaya. This research is a qualitative study using descriptive methods. Data collection is done by interview, observation, and study documentation. Data analysis techniques were carried out through descriptive interpretation, data validity test, extension of participation, and auditing. Library planning is carried out with musyarawah, organizing is done by selection and agreed upon together, implementation is carried out according to plan and according to their respective duties and supervision is carried out every day such as supervision of circulation services and cleanliness, tidiness and discipline. Collection development is carried out by deliberation and submission from the user, supporting factors are adequate facilities, inhibiting factors that the librarians available are not graduates from their fields.

Key Words: Management, Library, Interest In Reading

\section{PENDAHULUAN}

Pendidikan akan selalu menjadi kebutuhan manusia dalam menjalankan kehidupannya Untuk bisa meningkatkan kualitas pendidikan, maka diperlukan perpustakaan yang berkualitas sebagai salah satu penunjang proses pendidikan (Rahman, 2019). Perpustakaan merupakan salah satu sumber informasi yang diselenggarakan pada suatu lembaga pendidikan, dikelola sepenuhnya oleh lembaga yang bersangkutan, dengan tujuan utama mendukung terlaksananya dan tercapainya tujuan sekolah dan tujuan pendidikan pada umumnya. Sekolah merupakan tempat penyelenggaraan proses belajar mengajar, menanamkan dan mengembangkan berbagai nilai, ilmu pengetahuan, teknologi, keterampilan, seni, serta wawasan dalam rangka mencapai tujuan pendidikan nasional. Oleh karena itu, perpustakaan sekolah bukan hanya sekedar tempat penyimpanan bahan pustaka (buku dan non buku), tetapi terdapat upaya untuk mendayagunakan agar koleksi-koleksi yang ada dimanfaatkan oleh pemakainya secara maksimal. Hal ini dipertegas dalam SK Mendiknas No. 053/U/2001 tanggal 19 April 2001 tentang Penyusunan Pedoman Standar Pelayanan Minimal Penyelenggaraan Persekolahan pada Tingkat TK, Sekolah Dasar sampai dengan SMU/SMK, bahwa keberadaan perpustakaan sekolah merupakan syarat dalam Standar Pelayanan Minimal (SPM) tersebut. Sehubungan hal itu agar bahan pustaka, dapat didayagunakan secara maksimal sesuai dengan tujuan dan fungsi perpustakaan sekolah, maka tentunya diperlukan suatu manajemen perpustakaan sekolah yang memadai.

Manajemen dalam konsep dasar manajemen diatas, maka manajemen adalah proses pengelolaan yang memanfaatkan sumber daya manusia dan sumber daya lainnya melalui perencanaan, pengorganisasian, pelaksanaan dan 
pengawasan untuk mencapai tujuan yang diinginkan dengan efektif dan efisien. Perpustakaan berasal dari kata pustaka, menurut Kamus Besar Bahasa Indonesia pustaka artinya kitab. Dalam bahasa Inggris dikenal dengan library. Istilah ini berasal dari kata librer atau libri yang artinya buku, dari kata latin tersebut terbentuklah istilah libraries tentang buku. Dalam bahasa Belanda perpustakaan disebut dengan binliotheca yang juga berasal dari bahasa Yunani Biblia yang artinya tentang buku atau kitab (Suwarno, 2010).

Manajemen dalam perpustakaan dapat dibahasakan dengan melakukan kegiatan mengatur, mengarahkan, membimbing, mengendalikan, mempengaruhi staf atau pustakawan agar tetap dapat bekerja, berkarya, melakukan tugas-tugas kepustakawanan untuk mencapai tujuan perpustakaan. Dari pengertian ini manajemen di perpustakaan perlu untuk dipelajari, dipahami, dan direalisasikan oleh pemimpin perpustakaan agar tercapai tugas, fungsi dan tujuan perpustakaan (Iskandar, 2016, hlm. 7).

Manajemen merupakan sebuah kegiatan, pelaksanaannya disebut managing dan orang yang melakukannya disebut manager, individu yang menjadi manajer, tugas baru yang seluruhnya bersifat manageria, manajemen mencakup kegatan untuk mencapai tujuan yang dilakukan oleh individu-individu yang menyumbangkan upayanya yang terbaik melalui tindakan-tindakan manajemen yang telah ditetapkan sebelumnya (Mansyur, 2015).

Supyardi mengemukakan bahwa perpustakaan sekolah adalah perpustakaan yang diselenggarakan di sekolah guna menunjang program belajar mengajar di lembaga pendidikan formal tingkat sekolah baik sekolah dasar maupun sekolah menengah, baik sekolah umum maupun sekolah lanjutan. Sedangkan menurut Carter $\mathrm{V}$ Good bahwa perpustakaan merupakan koleksi yang diorganisasi di dalam suatu ruangan agar dapat digunakan oleh muridmurid dan guru-guru (Bafadal, 2015, hlm. 4).

Menurut Undang-Undang No 43 Tahun 2007 Pasal 1 Tentang Perpustakaan, disebutkan bahwa perpustakaan adalah institusi pengelola koleksi karya tulis, karya cetak dan karya rekam secara profesional dengan sistem yang baku guna memenuhi kebutuhan pendidikan, penelitian, pelestarian informasi dan rekreasi para pemustaka. Sedangkan menurut Wafford menjelaskan bahwa perpustakaan adalah salah satu organisasi sumber belajar yang menyimpan, mengelola dan memberikan bahan pustaka baik buku ataupun non-buku kepada masyarakat tertentu maupun masyarakat umum (Rokan, 2017).

Ruang lingkup kegiatan perpustakaan sangat terkait dengan pengertian perpustakaan sekolah. Terdapat tiga kegiatan utama perpustakaan, diantaranya yaitu penghimpunan, pengelolaan, dan penyebarluasan informasi. Dalam hal penghimpunan, tugas ini melipui kegiatan mencari, menyeleksi, dan mengisi perpustakaan dengan sumber informasi yang memadai atau lengkap, baik dalam arti jumlah, jenis, maupun mutu, semua ini disesuaikan dengan kebijakan organisasi, ketersediaan dana, keinginan pemakai, dan perkembangan mutakhir. Sedangkan dalam hal pengelolaan, tugasnya meliputi proses pengolahan, penyusunan, penyimpanan, dan pengemasan agar tersusun rapi, mudah dalam pencarian dan mudah dalam diakses oleh pemakai, serta merawat bahan pustaka. Pengerjaan pengolahan mencakup pemeliharaan dan perawatan agar seluruh koleksi perpustakaan tetap dalam kondisi bersih, utuh, dan baik. 
Sedangkan kegiatan mengelola dalam pengertian merawat adalah kegiatan yang dilaksanakan dalam rangka pemeliharaan dan perlindungan untuk menjaga nilainilai sejarah dan dokumentasi. Sedangkan kegiatan terakhir adalah penyebarluasan informasi, beberapa tugas yang termasuk dalam kegitan ini adalah pelayanan referensi dan informasi, pelayanan pinjaman koleksi, pelayanan promosi, pelayanan bimbingan kepada pembaca, dan lain sebagainya. Termasuk dalam hal ini adalah layanan kepada para siswa dan guru dalam rangka mencari informasi yang berkaitan denan bidang dan minat mereka (Prastowo, 2012, hlm. 59).

Peningkatan minat baca atau gemar membaca merupakan salah satu dari peran perpustakaan sebagai sumber atau penyedia informasi. Dengan demikian siswa diharapkan senantiasa memanfaatkan koleksi perpustakaan dalam rangka meningkatkan minat baca. UU No. 43 Tahun 2007 Bab XIII mengenai pembudayaan kegemaran membaca, pasal 48 ayat 3 menyatakan, bahwa pembudayaan kegemaran membaca pada satuan pendidikan sebagaimana dimaksud pada ayat 1 dilakukan dengan mengembangkan dan memanfaatkan perpustakaan sebagai proses pembelajaran.

Perpustakaan sebagai salah satu pusat informasi, dalam kacamata pendidikan peranannya cukup penting. Karena proses belajar mengajar dapat berjalan dengan efektif jika rujukannya tersedia. Melalui perpustakaan dengan sumber-sumber informasi yang ada didalamnya sedianya dapat membantu untuk meningkatkan mutu kualitas pendidikan (Rahadian dkk., 2014).

Terdapat ada lima tahap perkembangan membaca, yaitu kesiapan membaca, membaca permulaan, keterampilan membaca cepat, membaca luas dan membaca yang sesungguhnya (Triatma, 2016). Penggunaan perpustakaan mengungkapan bahwasanya ada cara lain dalam seseorang mendapatkan informasi, yaitu dengan memanfaatkan media elektronik seperti TV, radio sampai dengan smartphone. Akan tetapi hal itu tidak seharusnya menjadikan lupa akan karya cetak yang memberikan berita atau informasi secara aktual seperti artikel, koran bahkan buku (Aini, 2012).

Minat baca adalah kecenderungan atau keinginan hati yang tinggi untuk membaca (Siregar, 2005). Minat baca merupakan kecenderungan jiwa yang mendorong seseorang berbuat sesuatu terhadap membaca. Meningkatnya minat baca akan meningkatkan kualitas sumber daya manusia. Guru dan pustakawan merupakan ujung tombak dalam meningkatkan minat baca masyarakat. Perpustakaan bukan sekedar konsumsi pelajar dan mahsiswa. Oleh karena itu berbagai upaya harus diusahakan untuk meningkatkan minat baca masyarakat.

Minat sangat besar pengaruhnya terhadap belajar, karena bila bahan pelajaran yang dipelajari tidak sesuai dengan minat siswa maka tidak ada daya tarik baginya. Pelajaran yang menarik minat siswa, lebih mudah dipelajari dan mudah disimpan dalam ingatan, karena minat menambah giat belajar (Sari, 2016).

Lebih lanjut lagi disebutkan pada pasal 49 hingga 51 yang intinya bahwa pembudayaan gemar membaca dapat digerakkan melalui pemanfaatan perpustakaan. Namun pada kenyataannya pemanfaatan perpustakaan di Indonesia relatif rendah dan hanya $10 \%-20 \%$ dari jumlah pengunjung yang meminjam buku (Siahaan \& Rivalina, 2007). 
Proses pembelajaran merupakan inti dari proses pendidikan formal dengan guru sebagai pemeran utama. Guru yang kompeten dan profesional akan lebih mampu dalam menyampaikan materi pelajaran, sehingga hasil belajar siswa berada pada tingkat yang optimal. Guru merupakan faktor yang penting dalam meningkatkan kualitas pembelajaran. Namun bukan berarti keberadaan unsur-unsur lain tidak begitu penting bagi peningkatan minat baca peserta didik di sekolah. Guru membutuhkan layanan yang profesional di bidang sarana dan prasarana dalam menerapkan kemampuannya secara maksimal, salah satunya adalah perpustakaan.

Keberhasilan program pendidikan melalui proses pembelajaran sangat dipengaruhi oleh banyak faktor, salah satu diantaranya adalah tersedianya sumber informasi pendidikan yang memadai disertai pemanfaatan dan pengelolaan secara optimal. Perpustakaan merupakan salah satu sumber daya yang penting dan utama dalam menunjang proses pembelajaran di sekolah, untuk itu perlu dilakukan peningkatan dalam pendayagunaan dan pengelolaannya, agar tujuan yang diharapkan dapat tercapai.

Perubahan budaya merupakan salah satu tantangan paling sulit yang akan dihadapi oleh organisasi. Peran pimpinan puncak menjadi sangat penting. Kadang-kadang, budaya organisasi tidak bisa diubah tanpa perubahan dalam kepemimpinan. Perubahan budaya memerlukan dukungan, ide, dan kepemimpinan dari karyawan di semua tingkatan (Abdul, 2013).

Menurut Peter Scholtes, manajemen harus dimulai dengan mengembangkan pemahaman tentang peraturan dari perubahan organisasi, yaitu memahami sejarah dari budaya yang saat ini ada, jangan menyalahkan sistem namun meningkatkannya, bersiaplah untuk mendengar dan mengamati, dan libatkan semua orang yang terkena dampak dari perubahan (Iskandar, 2016).

Randall dan Godrich mengemukakan bahwa funsi koleksi perpustakaan ada empat, diantaranya: (1) fungsi referensi, maksudnya yaitu koleksi perpustakaan yang mempunyai fungsi referensi adalah koleksi perpustakaan yang dapat memberikan rujukan tentang berbagai informasi secara cepat, tepat dan akurat bagi para pemakainya; (2) fungsi kurikuler, maksudnya yaitu, bahanbahan pustaka yang mempunyai fungsi kurikuler adalah koleksi bahan-bahan yang mampu mendukung kurikulum. Jadi pustakawan sekolah harus dapat memenuhi kebutuhan para pemustaka melalui penyediaan berbagai bahan dan subjek (mata pelajaran) yang diajarkan di sekolah yang bersangkutan; (3) fungsi umum, maksudnya yaitu, fungsi koleksi perpustakaan yang bersifat umum ini berhubungan dengan pelestarian bahan pustaka dan hasil budaya manusia secara keseluruhan; dan (4) fungsi penelitian, maksudnya yaitu keberadaan koleksi perpustakaan sekolah harus mampu berfungsi memberikan jawaban atas keingintahuan dari pemakai perpustakaan. Dengan begitu, perpustakaan dapat dijadikan sarana yang menyediakan berbagai informasi yang dibutuhkan oleh para pemustaka atau peneliti dalam melakukan tugas mereka (Iskandar, 2016).

Berdasarkan studi pendahuluan di Madrasah Aliyah Negeri atau MAN 3 Tasikmalaya pada Desember 2018, Bapak Dedi Kusmayadi selaku Kepala Perpustakaan MAN 3 Tasikmalaya, mengungkapkan bahwasannya di MAN 3 Tasikmalaya masih menggunakan sistem manual dalam pencatatan peminjaman dan pengembalian buku, sehingga seringkali ada kehilangan buku yang 
berakibatkan kurangnnya akan sumber buku diperpustakaan, penggunaan perangkat lunak dalam pengelolaan perpustakaan masih belum maksimal, dalam artian perangkat lunak yang mengakses semua buku yang ada di perpustakaan tersebut tidak dapat digunakan dengan baik, sehingga peserta didik tidak sulit dalam pencarian buku. Informasi dan komunikasi antara perpustakaan dengan peserta didik yang belum maksimal sehingga peserta didik kurang mengetahui tentang sumber-sumber buku yang ada di perpustakaan, serta pengadaan buku yang belum sesuai dengan kebutuhan siswa. Sementara itu ada hal menarik mengenai perpustakaan MAN 3 Tasikmalaya, yaitu pemberian reward kepada peserta didik yang rajin ke perpustakaan untuk membaca buku, pemberian hadiah ini dilakukan setiap dua semester sekali, dan juga perpustakaan mengadakan program karya tulis ilmiah bagi setiap peserta didik.

\section{METODE}

Secara garis besar metodologi penelitian akan menjelaskan tahapan kegiatan yang dilakukan yaitu: 1) menentukan pendekatan dan metode penelitian, 2) menentukan jenis data dan sumber data, 3) teknik pengumpulan data, 4) teknik analisis data, 5) menentukan tempat dan waktu penelitian, dan 6) uji keabsahan data. Teknik pengumpulan data dilakukan ialah dengan teknik wawancara, observasi, dan studi dokumentasi. Peneliti melakukan wawancara melalui percakapan tanya jawab untuk memperoleh informasi dari narasumber. Observasi dilakukan melalui pengamatan baik secara langsung maupun tidak langsung dengan menggunakan seluruh pancaindera. Studi dokumentasi dilakukan untuk mengumpulkan dokumen dan data-data pendukung terkait dengan penelitian. Teknik analisis data penelitian dimulai dari analisis data sebelum di lapangan, analisis data di lapangan yaitu reduksi data, penyajian data, verifikasi/kesimpulan, dan analisis data selama di lapangan. Sedangkan teknik keabsahan data terdiri dari perpanjangan pengamatan, meningkatkan ketekunan, triangulasi, analisis kasus negatif, menggunakan bahan referensi dan mengadakan membercheck. Uji absah data dilakukan untuk membuktikan bahwa data yang diterima merupakan data yang sebenarnya terdapat pada tempat penelitian.

\section{HASIL DAN PEMBAHASAN \\ Penerapan Fungsi Manajemen Perpustakaan Madrasah Aliyah Negeri 3 Tasikmalaya}

Perencanaan pengadaan manajemen perpustakaan di MAN 3 Tasikmalaya dimulai dengan merencanakan sarana dan prasarana perpustakaan, pengadaan bahan pustaka dan perencanaan kerja perpustakaan. Sementara itu, fasilitas yang dimiliki perpustakaan MAN 3 Tasikmalaya sampai saat ini sudah terbilang lengkap, tetapi dengan adanya perencanaan pengadaan sarana dan prasarana ini upaya untuk mewujudkan perpustakaan yang nyaman bagi pemustaka.

Perpustakaan MAN 3 Tasikmalaya juga selalu merencanakan program kerja perpustakaan. Perencanaan kerja di perpustakaan MAN 3 Tasikmalaya meliputi perencanaan program kerja jangka pendek, perencanaan program kerja semesteran dan perencanaan program kerja tahunan yang dapat dirumuskan dalam program kerja. Beberapa perencanaan yang dilakukan oleh perpustakaan 
MAN 3 Tasikmalaya adalah menyusun program kerja demi kelancaran kegiatan di perpustakaan, maka perpustakaan MAN 3 Tasikmalaya menyusun program kerja jangka pendek (harian), program kerja semesteran, dan program kerja tahunan (jangka panjang).

Perpustakaan MAN 3 Tasikmalaya, dalam merencanakan program kerja selalu melibatkan kedua staf pustakawan, wakil kepala madrasah bagian kurikulum dan kepala madrasah serta wali kelas sebagai fasilitator siswa dan siswi dalam penyampaian pendapatnya mengenai pengadaan buku. Dengan tujuan tujuan menghasilkan perencanaan yang maksimal.

Pengorganisasian merupakan pengelompokan orang sesuai dengan kegiatan yang akan dilaksanakan dalam sebuah organisasi atau biasa disebut dengan struktur organisasi. Struktur organisasi adalah salah satu bagian yang menunjukan semua tugas kerjanya, hubungan fungsi-fungsi didalamnya, wewenang dan tanggung jawab setiap bagian kerja organisasi untuk mencapai tujuan yang telah direncanakan atau ditentukan. Tanpa adanya struktur organisasi perpustakaan bisa dikatakan tidak akan berjalan dengan baik, karen setiap bidang memerlukan petugasnya masing-masing supaya tidak terjadi ketimpangan dalam pelaksanaan tugas kepustakaan.

Struktur organisasi perpustakaan MAN 3 Tasikmalaya terdiri dari kepala madrasah, kepala perpustakaan, bagian non teknis, bagian teknis, dan bagian layanan. Pada perpustakaan MAN 3 Tasikmalaya ini pembagian tugasnya bukan fokus pada salah satu bidang, akan tetapi satu orang bisa memegang dua bidang seperti bagian teknis dan non-teknis.

Gaya kepemimpinan yang epektif menyatakan gaya kepemimpinan yang baik adalah gaya kepemimpinan yang dapat memberikan motivasi kerja pada bawahannya. Karyawan dapat memandang pimpinannya sebagai pemimpin yang efektif atau tidak, berdasarkan kepuasan yang mereka peroleh dari pengalaman kerja secara keseluruhan. Kinerja karyawan akan baik apabila pimpinan dapat dapat memberikan motivasi yang tepat dan pimpinan memiliki gaya kepemimpinan yang dapat diterima oleh seluruh karyawan dan mendukung terciptanya suasanan kerja yang baik (Ambarwati, 2015).

Tugas dan fungsi masing-masing bagian perpustakaan MAN 3 Tasikmalaya adalah kepala sekolah, kepala perpustakaan, bagian non teknis, bagian teknis, dan bagian layanan. Kepala madrasah, merupakan penanggung jawab seluruh kegiatan di perpustakaan dan bertugas memberikan arahan, bimbingan dan pengawasan kepada kepala perpustakaan. Sedangkan kepala perpustakaan adalah pemimpin atau pengelola perpustakaan dan bertugas melakukan perencanaan, pengarahan atau penggerakan, pelaksanaan dan pengawasan kegiatan-kegiatan di perpustakaan dan kepala perpustakaan bertanggungjawab kepada kepala madrasah. Yang ketiga adalah bagian non teknis perpustakaan yang bertugas mengelola administrasi atau ketatausahaan dan kegiatan non teknis di perpustakaan, bagian non teknis perpustakaan bertanggungjawab kepada kepala perpustakaan. Yang ke empat adalah bagian teknis perpustakaan yang bertugas melakukan pengadaan koleksi pengadaan koleksi, mengolah otomasi dan digital library. Bagian teknis bertanggungjawab kepada kepala perpustakaan. Dan yang ke lima adalah bagian layanan perpustakaan yang bertugas melakukan pelayanan perpustakaan dan promosi 
perpustakaan. Bagian layanan perpustakaan bertanggung jawab kepada kepala perpustakaan.

Penggerakan (Actuating) dapat dilaksanakan setelah adanya perencanaan dan pengorganisasian, sebab penggerakan merupakan pelaksanaan dari proses perencanaan dan pengorganisasian. Penggerakan di perpustakaan MAN 3 Tasikmalaya yaitu pelayanan. Pelayanan di perpustakaan MAN 3 Tasikmalaya maksudnya tenaga perpustakaan bukan hanya melayani peminjaman, pengembalian dan perpanjangan buku saja, akan tetapi ada beberapa layanan lain yang di sediakan, yaitu layanan sirkulasi, layanan bimbingan pemakai, layanan literasi informasi, layanan referensi, layanan kemas ulang informasi serta layanan ruang baca dan diskusi.

Layanan sirkulasi dilakukan dengan sisitem terbuka, yaitu pemakai bisa langsung memilih dan mengambil sendiri bahan pustaka yang di perlukan. Pada dasarnya sirkulasi melayani peminjaman, pengembalian dan perpanjangan bahan pustaka.

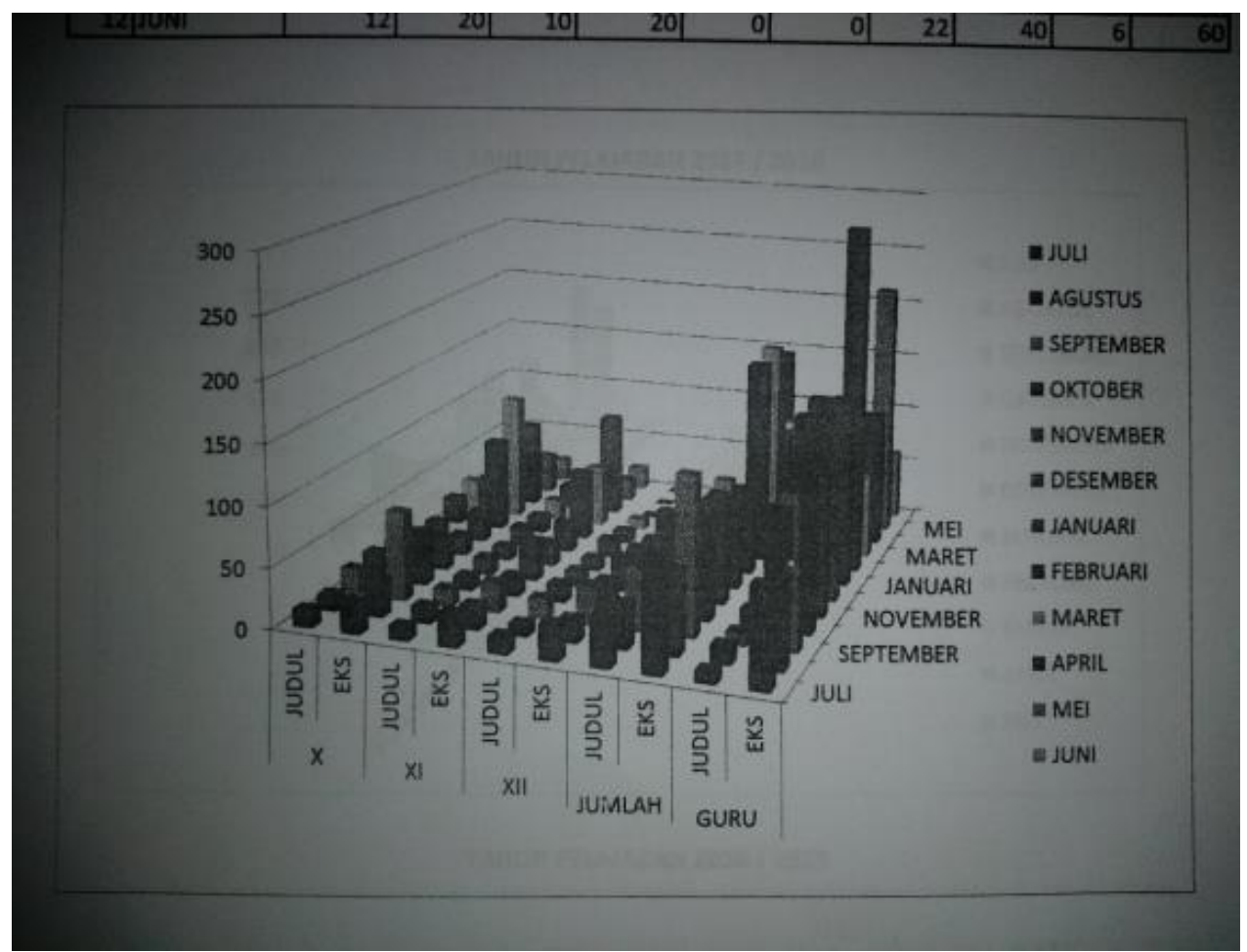

Sumber: dokumen laporan dan rekap pinjaman buku perpustakaan

Gambar 1. Frekuensi Siswa Yang Meminjam Buku Perpustakaan

Selain layanan sirkulasi terdapat juga layanan bimbingan pemakai, layanan ini diberikan kepada pemakai yang membutuhkan bimbingan dalam pemakaian perpustakaan terutama dalam penelusuran informasi. Layanan ketiga adalah layanan literasi informasi, layanan ini dapat diberikan kepada guru yang membutuhkan kerjasama dengan pustakawan dalam proses pembelajaran, tetapi pemakai layanan ini harus terlebih dahulu untuk menghubungi pustakawan. Layanan yang keempat adalah layanan referensi, layanan ini di MAN 3 Tasikmalaya diberikan kepada pemustaka yang memakai referensi bahan pustaka referensi hanya boleh dibaca di tempat dan tidak boleh dipinjam untuk 
dibawa pulang, koleksi referensi dapat berupa kamus, ensiklopedia, sumber geografis, panduan, bibliografi, karya tulis siswa dan murid serta pedoman. Layanan yang kelima adalah layanan kemas ulang informasi. Di perpustakaan MAN 3 Tasikmalaya menyediakan layanan kemas ulang informasi dalam bentuk sederhana, yang dimaksud layanan ini adalah penyediaan layanan jasa informasi yang dimulai dari menyeleksi berbagai informasi dari berbagai sumber yang berbeda. Mendata informasi yang relevan, menganalisis, menyintesis, dan menyajikan informasi yang sesuai dengan kebutuhan pemustaka. Layanan yang terakhir yaitu layanan ruang baca dan diskusi. Layanan yang disediakan oleh perpustakaan dan di tata oleh pustakawan berupa tempat untuk kegiatan membaca dan berdiskusi di tempat bagi mereka yang tidak berminat meminjam buku perpustakaan untuk dibawa pulang. Perpustakaan MAN 3 Tasikmalaya menyediakan jam pelayanan seperti dengan jam masuk pelajaran sampai dengan akhir pelajaran.

Dalam pelaksanaan program kerja, tugas dan tanggung jawab di perpustakaan sangat perlu adanya pengawasan untuk mengetahui seberapa jauh ketercapaian program terebut terlaksanakan, dan seberapa efektif dan efisien pelaksanaan program kerja perpustakaan. Hal tersebut diharapkan dapat ditingkatkan dan menjamin aktivitas-aktivas yang dilakukan, sehingga dapat memberikan hasil yang memuaskan sesuai dengan yang direncanakan.

Pengawasan di perpustakaan MAN 3 Tasikmalaya dilaksanakan oleh kepala madrasah dan kepala perpustakaan. Pengawasan yang dilakukan oleh kepala madrasah waktunya tidak tentu, kadang 1 minggu satu kali atau satu bulan satu kali. Hal yang menjadi pokok pengawasan adalah seperti kebersihan perpustakaan, kerapihan buku, dan kunjungan siswa ke perpustakaan.

Sedangkan pengawasan yang dilakukan oleh kepala perpustakaan yaitu setiap hari, walaupun kepala perputakaan mempunyai jadwal mengajar. Alasannya karena ruang meja kepala perpustakaan adanya di perpustakaan menyatu dengan meja tugasnya sebagai guru. Pengawasan yang dilakukan oleh kepala perpustakaan diantaranya mengenai melakukan pengawasan kinerja petugas perpustakaan, melakukan pengawasan kebersihan perpustakaan, melakukan pengawasan kerapihan dan penataan koleksi buku pada rak di perpustakaan, melakukan pengawasan sirkulasi (peminjaman, pengembalian dan perpanjangan) tujuan untuk melihat jumlah buku yang di pinjam, buku yang paling sering di pinjam dan buku yang belum dikembalikan dan melakukan pengawasan fasilitas yang ada di perpustakaan.

\section{Pengembangan Koleksi Perpustakaan MAN 3 Tasikmalaya}

Koleksi perpustakaan adalah keseluruhan bahan pustaka yang dikumpulkan atau dihimpun oleh perpustakaan. Dengan tujuan untuk disiapkan atau disajikan untuk para pemustaka atau para pemakai. Sedangkan menurut Proyek Pembakuan Sarana Pendidikan Departemen Pendidikan dan Kebudayaan, koleksi perpustakaan adalah sekumpulan sumber informasi dalam berbagai bentuk yang telah dipilih sesuai dengan program sekolah yang bersangkutan, mencakup dan menunjang semua bidang studi, memberikan semua pengetahuan umum yang sesuai dengan tingkat kecerdasan, kemampuan membaca, serta perkembangan jiwa murid dan tuntutan profesi guru (Kurniawati \& Prajarto, 2015). 
Pengembangan koleksi perpustakaan di MAN 3 Tasikmalaya meliputi kebijakan pengembangan koleksi, pemilihan bahan pustaka, dan cara pengadaan bahan pustaka.

Dalam hal kebijakan perpustakaan MAN 3 Tasikmalaya merupakan upaya untuk mengarahkan suatu kegiatan agar menjadi lebih baik dengan berbagai cara seperti membuat peraturan, menyusun strategi dan menetapkan arah atau prosedur. Dalam menetapkan kebijakan perpustakaan koleksi perpustakan MAN 3 Tasikmalaya terdapat beberapa hal yang perlu diperhatikan, pengembangan koleksi harus sesuai dengan visi, misi dan tujuan perpustakaan MAN 3 Tasikmalaya, pengembangan koleksi harus sesuai dengan kebutuhan pemakai, pengembangan koleksi harus menyesuaikan dengan anggaran yang tersedia, tim koleksi terdiri dari kepala madrasah, kepala perpustakaan, guru dan siswa, penerimaan buku sumbangan dan hadiah harus sesuai dengan kebijakan pengembangan koleksi.

Setelah pengadaan koleksi dilakukan sesuai dengan kebijakan pengembangan koleksi, maka tahap berikutnya adalah pengolahan koleksi. Pada perpustakaan MAN 3 Tasikmalaya pengolahan koleksi perpustakaan dilakukan dengan empat kegiatan. Yaitu katalogisasi, klasifikasi, pencantuman kelengkapan bahan pustaka dan entri data bahan pustaka.

Katalogisasi di perpustakaan MAN 3 Tasikmalaya meliputi deskripsi bibliografi dan analisis subjek. Dalam membuat deskripsi bibliografi, perpustakaan MAN 3 Tasikmalaya berpedoman pada AACR (Anglo America Cataloging Rules). Sedangkan analisis subjek merupakan kegiatan menentukan subjek yang terkandung dalam suatu bahan pustaka. Untuk menentukan suatu subjek bahan pustaka seorang pustakawan harus membaca dulu buku tersebut, mulai dari judul, kata pengantar, daftar isi, abstrak dan apabila diperlukan membaca sebagian atau semua isi buku.

Klasifikasi adalah kegiatan untuk menentukan nomor kelas suatu bahan pustaka untuk mempermudah menata dan menemukan kembali bahan pustaka sesuai dengan klasifikasi. Dalam menentukan klasifikasi manajemen perpustakaan MAN 3 Tasikmlaya berpedoman pada DDC (dewey decimal classification). Bagan klasifikasi DDC terdiri dari 10 kelas utama masing-masing kelas utama dibagi menjadi 10 divisi, masing-masing divisi dibagi lagi menjadi 10 seksi dan masing-masing seksi di bagi menjadi 10 subseksi. Contoh kelas utama adalah nomor kelas dapat dilihat langsung ke bagan atau menggunakan indeks dulu, baru masuk ke bagan. Secara umum dalam menentukan nomor klasifikasi harus menggunakan DDC yang didalamnya terdiri dari bagan, indeks relatif dan tabel tambahan. Selain itu dalam klasifikasi buku juga perlu ditambah dengan tajuk subjek sedangkan untuk klasifikasi buku-buku islam menggunakan klasfikasi islam dan daftar tajuk subjek islam dalam hasil pengembangan Departemen Agama.

Dalam pencantuman kelengkapan bahan pustaka, setiap bahan pustaka yang telah dikatagolisasi harus diberi kelengkapan berupa nomor register, stempel perpustakaan, stempel milik pada halaman tertentu, kantong buku, lidah buku, nomor panggil/punggung buku, barcode bahan pustaka, dan sampul buku bila diperlukan. Kemudian tahap terakhir dalam pengolahan koleksi perpustakaan MAN 3 Tasikmalaya adalah entri data bahan pustaka, kegiatannya 
meliputi memasukan data pada buku induk dan memasukan data pada data base automasi perpustakaan

Di perpustakaan MAN 3 Tasikmalaya pemilihan bahan pustaka dilaksanakan berdasarkan beberapa pertimbangan, seperti permintaan pengguna, dampak yang akan dihasilkan dari buku tersebut, hasil diskusi dengan pustakawan, guru dan kepala madrasah. Otomatis buku yang mengandung unsur kriminalisasi dan unsur SARA tidak akan menjadi pilihan walaupun dalam jumlah sedikit.

Pengadaan bahan pustakan di perpustakaan MAN 3 Tasikmalaya sampai saat ini dilakukan dengan dua cara, yaitu dengan pembelian dan hibah. Untuk cara pembelian, buku yang diadakan adalah buku-buku pelajaran dan dilaksanakannya setiap tahun atau setiap ganti kurikulum, karena besar kemungkinan juga ada pergantian kurikulum akan berdampak pada kebutuhan koleksi pustaka. Serta permintaan dari pemustaka mengenai bahan pustaka yang dibutuhkan, akan tetapi hal ini disesuaikan dengan keadaan anggaran.

Sedangkan pengadaan koleksi buku dengan cara hibah atau hadiah didapatkan dari dua sumber, yaitu setiap akhir tahun siswa dan siswi yang akan lulus dianjurkan menghibahkan buku kepada madrasah akan tetapi tidak dalam paksaan dan tidak ditentukan buku apa yang harus dihibahkan, baik itu berupa buku fiksi, non-fiksi, pelajaran, agama, atau referensi asalkan tidak mengandung kriminalisasi dan SARA serta bukunya harus cocok untuk digunakan di MAN 3 Tasikmalaya. Dan pengadaan buku yang selanjutnya yaitu dari kepala madrsah dan waktunya tidak tentu, pengajuannya berawal dari siswa kepada guru, disampaikan kepada pustakawan dan kepala perpustakaan menyampaikannya kepada kepala madrasah. Karena permintaan datang dari siswa, maka kebanyakan permintaan yang diinginkan adalah buku fiksi.

\section{Faktor Penunjang dan Penghambat Manajemen Perpustakaan}

Dalam prosesnya, manajemen tidak akan pernah terlepas dari faktor penunjang dan penghambat. Yang pastinya hal tersebut juga pasti ada pada manajemen perpustakaan, faktor penunjang adalah segala sesuatu yang dapat mendukung proses pelaksanaan manajemen perpustakaan, sedangkan faktor penghambat adalah segala sesuatu yang dapat menghabat keterlaksanaan manajemen perpustakaan dengan lancar. Yang termasuk factor penunjang manajemen perpustakaan MAN 3 Tasikmalaya yaitu: 1) pustakawan yang memadai yaitu kepala perpustakaan dan 2 orang yang bertugas di perpustakaan, 2) anggota yang terdiri dari siswa dan siswi MAN 3 Tasikmalaya yang cukup banyak, sehingga perpustakaan selalu dikunjungi setiap harinya, 3) sarana yang tersedia sebagian besar sudah menunjang dalam proses pelayanan, contohnya meja baca dan meja diskusi yang sudah memadai. Dan juga ada tempat lesehan untuk pemustaka yang akan membaca, 4) letak perpustakaan sangat staregis, perpustakaan Madrasah Aliyah Negeri 3 Tasikmalaya berada di tengah lokasi madrasah yang akan memudahkan bagi pemustaka untuk menjangkaunya, baik untuk tenaga pendidik ataupun untuk peserta didik, dan 5) lingkungan MAN 3 Tasikmalaya sangat mendukung adanya sebuah perpustakaan. Karena perpustakaan merupakan sumber untuk belajar yang menyediakan berbagai informasi yang dibutuhkan oleh peserta didik dan tenaga pendidik untuk mendukung proses pembelajaran. 
Sedangkan yang menjadi faktor penghambat dalam manajemen perpustakaan MAN 3 Tasikmalaya adalah: 1) kualitas pustakawan yang belum sesuai dengan keahlian, karena sebagian petugas bukan lulusan dari program studi perpustakaan. Akan tetapi dalam peningkatan keterampilan dalam kinerja di perpustakaan selalu mengikuti latihan dan penataran, 2) masih banyak anggota yang kurang sadar akan pentingnya perpustakaan dan mengunjunginya untuk belajar atau membaca buku, 3) guru-guru masih jarang untuk berkunjung ke perpustakaan, seharusnya guru rajin untuk berkunjung ke perpustakaan untuk menambah bahan pelajaran dan sekalian memberikan contoh kepada para siswa dan siswi, 4) ada sebagian buku yang masih kurang lengkap untuk bahan ajaran, hal ini dikarenakan adanya pergantian kurikulum pada tahun ajaran 2017/2018, terutama untuk kelas XII, 5) sebagian sarana sudah ada yang rusak, seperti rak buku dan meja untuk membaca serta ada buku-buku yang sudah rusak, 6) perpustakaan masih menggunakan sistem manual dalam pelayanannya, tetapi untuk rekapitulasi sirkulasi dan penyimpanan data lainnya sudah menggunakan komputer.

\section{Hasil Manajemen Perpustakaan}

Hasil merupakan akumulasi dari sebuah usaha yang dilaksanakan secara bersama dan bekerja sama dengan berbagai komponen-komponen dalam mengelola perpustakaan MAN 3 Tasikmalaya yang berjalan secara terorganisisr, dalam persepektif pustakawan MAN 3 Tasikmalaya memberikan pelayanan yang terbaik kepada pemustaka, dan kenyamanan yang dirasakan oleh pengguna perpustakaan adalah suatu keberhasilan yang sangat dibanggakan. Karena bagi para pustakawan dengan latar belakang yang bukan ahli dibidangnnya yang hanya berbekal pelatihan dan penataran, hal tersebut merupakan suatu kebanggaan. Sehingga hasilnya adalah siswa dan siswi selalu ramai datang ke perpustakaan meskipun masih belum semuanya.

Bukan hanya dalam proses pelayanan saja, hasil manajemen perpustakaan MAN 3 Tasikmalaya dari mulai perencanaan, pengorganisasian, penggerakan dan pengawasan semuanya lancar, hal tersebut dapat terlihat salah satunya dari efektivitas dan ketercapaian program kerja perpustakaan baik itu program kerja jangka pendek, semesteran ataupun jangka panjang. Untuk peningkatan jumlah pengunjung tentunya hal tersebut waktunya tidak tentu setiap harinya, tapi yang pasti setiap awal tahun pelajaran pengunjung selalu ramai dari biasanya dan peningkatan pengunjungnya signifikan di bandingkan dengan hari-hari biasanya karena ada buku-buku terbaru.

Hal mengenai keberhasilan perpustakaan juga sangat dirasakan oleh pengguna perpustakaan dalam hal ini beberapa siswa dan siswi di wawancarai, mereka mengungkapkan bahwa perpustakaan sangat memberikan manfaat, serta untuk koleksi, fasilitas dan layanan sangat memuaskan.

Dalam catatan laporan dan evaluasi program kerja perpustakaan tahun pelajaran 2018/2019, bahwa perpustakaan MAN 3 Tasikmalaya memiliki anggota seluruh siswa dan siswi yang berjumlah 843 orang, sedangkan untuk jumlah koleksi bukunya sendiri berjumlah 30.345. Perpustakaan MAN 3 Tasikmalaya dari tahun ke tahun mengalami penambahan, baik itu berupa koleksi buku ataupun dari fasilitas perlengkapan perpustakaan. Dan peningkatan disetiap 
aspek terutama pelayanan, hal tersebut dilakukan semata-mata untuk memberikan kepuasan terhadap pengguna perpustakaan.

\section{SIMPULAN}

Pendirian Perpustakaan MAN 3 Tasikmalaya, yaitu karena perpustakaan merupakan salah satu jantungnya madrasah dalam memperoleh ilmu dan informasi. Selain itu juga dengan adanya perpustakaan diharapkan semua civitas MAN 3 Tasikmalaya dapat selalu memperbaharui dan menambah wawasan keilmuannya. Sehingga kualitas dari seluruh civitas MAN 3 Tasikmalaya semakin meningkat dari segi prestasi baik di lingkup sekolah ataupun diluar sekolah. Perencanaan manajemen perpustakaan di MAN 3 Tasikmalaya dimulai dengan merencakan sarana prasarana perpustakaan, pengadaan bahan pustaka dan perencanaan perpustakaan. Sementara itu, fasilitas yang dimiliki perpustakaan MAN 3 Tasikmalaya sampai saat ini sudah terbilang lengkap, tetapi dengan adanya perencanaan pengadaan sarana dan prasarana ini upaya untuk mewujudkan perpustakaan yang nyaman bagi pemustaka.

Penggerakan di perpustakaan MAN 3 Tasikmalaya yaitu pelayanan, beberapa layanan lain yang di sediakan, yaitu layanan sirkulasi, layanan bimbingan pemakai, layanan literasi informasi, layanan referensi, layanan kemas ulang informasi serta layanan ruang baca dan diskusi. Pengawasan di perpustakaan MAN 3 Tasikmalaya dilaksanakan oleh kepala madrasah dan kepala perpustakaan. Pengembangan koleksi harus sesuai dengan visi, misi dan tujuan perpustakaan MAN 3 Tasikmalaya. Pengembangan koleksi harus sesuai dengan kebutuhan pemakai, pengembangan koleksi harus menyesuaikan dengan anggaran yang tersedia. Pemilihan bahan pustaka dilaksanakan berdasarkan beberapa pertimbangan, seperti permintaan pengguna, dampak yang akan dihasilkan dari buku tersebut, hasil diskusi dengan pustakawan, guru dan kepala madrasah. Faktor penunjang di perpustakaan MAN 3 Tasikmalaya diantaranya, pustakawan yang beranggotakan tiga orang, fasilitas yang sudah memadai serta lokasi yang strategis sedangkan untuk penghambatnya ialah kualitas dari pustakawan yang masih kurang maksimal karena bukan lulusan dari bidang perpustakaan, kurang sadarnya anggota akan pentingnya perpustakaan dan saran perpustakaan yang sebagian sudah rusak. Perpustakaan MAN 3 Tasikmalaya dari tahun ketahun mengalami penambahan, baik itu berupa koleksi buku ataupun dari fasilitas perlengkapan perpustakaan. Dan peningkatan disetiap aspek terutama pelayanan, hal tersebut dilakukan semat-mata untuk memberikan kepuasan terhadap pengguna perpustakaan.

\section{REFERENSI}

Abdul, R. (2013). Pengaruh Karakteristik Individu,Motivasi dan Budaya Kerja Terhadap Kinerja Pegawai Pada Badan Keluarga Berencana dan Pemberdayaan Perempuan Kabupaten Donggala. E-Journal KATALOGIS, http://jurnal.untad.ac.id/jurnal/index.php/Katalogis/article/view/3176

Aini, P. (2012). Penggunaan Perpustakaan Dalam Meningkatkan Minat Baca Siswa (Studi Kasus Sekolah An-Nisaa Pondok Aren Bintaro) [Skripsi, UIN Syarif Hidayatullah http://repository.uinjkt.ac.id/dspace/handle/123456789/5867 Jakarta]. 
Ambarwati, N. (2015). Gaya Kepemimpinan Yang Efektif Dalam Upaya Meningkatkan Kinerja Karyawan Pada PT Sumber Mas Indah Plywood. Jurnal Akuntansi AKUNESA, 3(3), 1-25.

Bafadal, I. (2015). Pengelolaan Perpustakaan Sekolah. PT Bumi Aksara.

Iskandar. (2016). Manajemen dan Budaya Perpustakaan. PT Refika Aditama.

Kurniawati, R. D., \& Prajarto, N. (2015). Peranan Perpustakaan Dalam Meningkatkan Minat Baca Masyarakat (Survei Pada Perpustakaan Umum Kotamadya Jakarta Selatan). Berkala Ilmu Perpustakaan dan Informasi, 3(7). https://doi.org/10.22146/bip.8271

Mansyur, M. (2015). Manajemen Perpustakaan Sekolah. Pustakaloka: Jurnal Kajian Informasi dan Perpustakaan, 7(1). https://doi.org/10.21154/pustakaloka.v7i1.184

Prastowo, A. (2012). Manajemen Perpustakaan Sekolah Profesional. Diva Press.

Rahadian, G., Rohanda, R., \& Anwar, R. K. (2014). Peranan Perpustakaan Sekolah Dalam Meningkatkan Budaya Gemar Membaca. Jurnal Kajian Informasi dan Perpustakaan, 2(1), 47. https://doi.org/10.24198/jkip.v2i1.11628

Rahman, T. M. A. (2019). Manajemen Perpustakaan Berbasis Sistem Otomasi. Jurnal Isema: Islamic Educational Management, 3(2), 114-124. https://doi.org/10.15575/isema.v3i2.5015

Rokan, M. R. (2017). Manajemen Perpustakaan Sekolah. IQRA': Jurnal Perpustakaan dan Informasi, 11(1), 88. https://doi.org/10.30829/iqra.v11i01.795

Sari, P. (2016). Minat Baca Siswa Kelas XI SMK Negeri 1 Kebumen Terhadap Novel Populer. Jurnal Pendidikan Bahasa dan Sastra Indonesia, 5(9), 19.

Siahaan, S., \& Rivalina, R. (2007). Strategi Meningkatkan Minat Baca: Menjadikan Membaca Sebagai Kebiasaan Hidup Sehari-Hari. Jurnal TEKNODIK, 11(2), 168-186.

Siregar, A. R. (2005). Manajemen Pengetahuan: Perspektif Pustakawan. PUSTAHA: Jurnal Studi Perpustakaan dan Informasi, 1(1). http://puslit2.petra.ac.id/ejournal/index.php/pus/article/view/17239

Suwarno, W. (2010). Pengetahuan Dasar Kepustakaan. Ghalia Indonesia.

Triatma, I. N. (2016). Minat Baca Pada Siswa Kelas VI Sekolah Dasar Negeri Delegan 2 Prambanan Sleman Yogyakarta. E-Jurnal Skripsi Program Studi Teknologi Pendidikan, 5(6), 166-178. 